\title{
Thrombin Induction of Plasminogen Activator-Inhibitor in Cultured Human Endothelial Cells
}

\author{
Thomas D. Gelehrter and Rita Sznycer-Laszuk \\ Departments of Internal Medicine and Human Genetics, University of Michigan Medical School, Ann Arbor, Michigan 48109-0618
}

\begin{abstract}
We have examined the effect of thrombin on the activity of plasminogen activator (PA) and plasminogen activator-inhibitor (PAI) in medium conditioned by primary cultures of human umbilical vein endothelial cells. PA activity was measured by fibrinolytic and esterolytic assays, and total tissue-type PA (tPA) antigen by radioimmunoassay. Net PA-I activity was assayed by titration of human urokinase esterolytic activity. Incubation of confluent endothelial cell cultures with thrombin for $24 \mathrm{~h}$ caused a sixfold increase in PA-I activity. The effect of thrombin was half-maximal at $\sim 0.4 \mathrm{U} / \mathrm{ml}(<4 \mathrm{nM})$, and required concomitant RNA and protein synthesis. The stimulation of PA-I activity required active $\alpha$-thrombin and was not obtained with $\boldsymbol{\gamma}$-thrombin nor with thrombin catalytically inactivated with hirudin. Because of the excess of PA-I, PA activity was not measurable in either control or thrombin-treated cells. Thrombin did, however, increase medium concentration of tPA antigen by approximately fourfold. The thrombin-induced PA-I inhibited both TPA and urokinase, did not lose activity upon acidification, and was stable to sodium dodecyl sulfate and thiol reduction. We conclude that physiologic concentrations of thrombin increase both PA-I activity and tPA antigen in medium conditioned by human umbilical vein endothelial cells. Because there was always a several-fold increase in the net activity of free PA-I, these observations suggest that the net effect of thrombin is to decrease fibrinolytic activity in human endothelial cells. Thus, thrombin, in addition to its role in coagulation, may protect clots from premature lysis by increasing the amount of a specific fibrinolytic inhibitor.
\end{abstract}

\section{Introduction}

The vascular endothelium, in addition to its well-recognized role in hemostasis, plays an important role in fibrinolysis (1). Human and bovine endothelial cells secrete both plasminogen activators (PAs) ${ }^{1}$ and a specific rapidly acting inhibitor of plasminogen activator (2-5). Thrombin, a key component of the

This work was presented in part at the Annual Meeting of the American Society of Clinical Investigation, Washington, DC, 3-6 May 1985, and published in abstract form (1985. Clin. Res. 33:546A).

Address reprint requests to Dr. Gelehrter, Department of Human Genetics, Box 0618, University of Michigan Medical School, Ann Arbor, MI 48109-0618. 1985.

Received for publication 5 July 1985 and in revised form 4 September

1. Abbreviations used in this paper: PA, plasminogen activator; PA-I, PA-inhibitor; tPA, tissue type PA: uPA, urokinase-like PA.

J. Clin. Invest.

(c) The American Society for Clinical Investigation, Inc. $0021-9738 / 86 / 01 / 0165 / 05 \$ \$ 1.00$

Volume 77, January 1986, 165-169 coagulation system (6), can also modulate fibrinolysis. Thrombin directly causes the release of plasminogen activator-inhibitor (PA-I) from human platelets (7) and decreases PA activity in cultured bovine aortic endothelial cells (8). The recently reported activation of protein $\mathrm{C}$ by thrombin (9) suggests that thrombin may paradoxically enhance fibrinolysis. The objective of this study was to examine the thrombin regulation of PA and PA-I activity in cultured human endothelial cells.

We have reported previously that glucocorticoids rapidly decrease PA activity in cultured rat hepatoma cells secondary to a 10-fold induction in the amount of PA-I without any decrease in the amount of PA (10-13). We report here that physiologic concentrations of thrombin cause a time- and concentration-dependent increase in the activity of PA-I in serum-free medium conditioned by primary cultures of human umbilical vein endothelial cells. Although thrombin also causes an increase in the release of tissue-type PA (tPA) antigen, there is always a several-fold increase in the net activity of free PA-I so that the net effect of thrombin may be to decrease fibrinolytic activity. Thus thrombin, in addition to its role in coagulation, may protect clots from premature lysis by increasing the amount of a specific fibrinolytic inhibitor.

\section{Methods}

Materials. Two preparations of human $\alpha$-thrombin were used in these studies. One (2,666 NIH U/mg) was purchased from Sigma Chemical Co., St. Louis, MO; the other $(3,767 \mathrm{U} / \mathrm{mg})$ was kindly provided by $\mathrm{Dr}$. J. W. Fenton II, New York Department of Health, Albany, NY, who also provided $\gamma$-thrombin $(0.92 \mathrm{U} / \mathrm{mg})$. Recombinant human tPA was a generous gift from Genentech, Inc., South San Francisco, CA, and rabbit anti-human melanoma tPA antiserum was kindly provided by Dr. Desire Collen, University of Leuven, Belgium. Plasminogen was prepared from oudated human plasma by affinity chromatography on lysine-Sepharose (Pharmacia Fine Chemicals, Piscataway, NJ) by the method of Deutsch and Mertz (14). High molecular weight human urokinase, bovine fibrinogen, Cbz-L-lysyl thiobenzyl ester, and 5,5'-dithiobis (2-nitrobenzoic acid) were purchased from Calbiochem-Behring Corp., La Jolla, CA. Actinomycin D was obtained from Merck and Co., Rahway, $\mathrm{NJ}$, and hirudin and cycloheximide were purchased from Sigma Chemical Co. Para-aminobenzamidine-Sepharose CL 4B and Iodgen were purchased from Pierce Chemical Co., Rockford, IL. Protein A was purchased from Miles Laboratories, Naperville, IL; $\mathrm{Na}^{125}$ I from New England $\mathrm{Nu}$ clear, Boston, MA; and ${ }^{125} \mathrm{I}$-labeled human fibrinogen $(140 \mu \mathrm{Ci} / \mathrm{mg})$ from Amersham Corp., Arlington Heights, IL.

Cell culture. Endothelial cell cultures were obtained from Dr. Stephen Weiss' laboratory at the University of Michigan. Endothelial cells were prepared from human umbilical cord veins by collagenase treatment as described by Jaffe et al. (15). All preparations were made from cells combined from several umbilical cords. Approximately $10^{4}$ cells were plated on gelatin-coated 35-mm dishes in $2 \mathrm{ml}$ of M199 (Gibco, Grand Island, NY) containing Hanks salts, $25 \mathrm{mM}$ Hepes, penicillin, streptomycin, and fungizone. The medium was supplemented with $100 \mu \mathrm{g} / \mathrm{ml}$ endothelial cell growth supplement (16) purchased from Collaborative Research, Waltham, MA, and $20 \%$ human serum. Human serum was collected from a panel of donors and was not heat-inactivated. The cul- 
tures were allowed to grow to confluence (5-7 d) at which time they contained $\sim 8 \times 10^{5}$ cells/dish (100-150 $\mu \mathrm{g}$ protein/dish). Confluent primary cultures were used for all experiments. The cultures were washed three times with $2 \mathrm{ml}$ serum-free medium at $37^{\circ}$ and incubated in $2 \mathrm{ml}$ serum-free medium with additions as described in the legends to the figures and tables. After incubation, medium was collected, made $0.01 \%$ with Tween 80 , centrifuged at $1,200 \mathrm{~g}$ to remove cell debris, and frozen at $-20^{\circ}$ until assayed. Before assay, thrombin activity was neutralized by incubation with hirudin ( $2 \mathrm{U} / \mathrm{unit}$ thrombin) for $20 \mathrm{~min}$ at $0^{\circ}$.

Assay of PA activity. Primary cultures of human endothelial cells contain and release tPA but not urokinase-like PA (uPA) (2-4). PA activity was measured either by an ${ }^{125} \mathrm{I}$-fibrin plate assay as described previously (13) or by a modification of the two-step esterolytic assay described by Coleman and Green (17). The latter assay was adapted for measurement of tPA activity by the addition of $220 \mu \mathrm{g} / \mathrm{ml}$ of cyanogen bromidedigested fibrinogen (18) and was sensitive to as little as $5 \mathrm{pg}$ of tPA.

Radioimmunoassay of $t P A$. Recombinant human tPA was iodinated to a specific activity of $\sim 36 \mu \mathrm{Ci} / \mu \mathrm{g}$ by the Iodogen method (19). Benzamidine was present during iodination to protect the active site and iodinated tPA was purified by affinity chromatography on $p$-aminobenzamidine-Sepharose 4B with elution of active enzyme by $1 \mathrm{mM} \mathrm{HCl}, \mathrm{pH}$ 3 , with $0.1 \%$ bovine serum albumin. Anti-human melanoma tPA IgG was prepared from rabbit antiserum by chromatography on protein Aagarose (20). Radioimmunoassay was carried out by modification of the method of McGregor and Prowse (21). tPA (10-1,000 pg in $120 \mu \mathrm{l})$ was incubated overnight at $4^{\circ} \mathrm{C}$ with $15 \mu \mathrm{l}$ of specific IgG $(1.6 \mathrm{ng}) .15 \mu \mathrm{l}$ of ${ }^{125}$ I-labeled tPA $(\sim 20,000 \mathrm{cpm})$ was then added and incubated for $1 \mathrm{~h}$ at $37^{\circ} \mathrm{C}$. One $\mathrm{ml}$ of $0.25 \%$ protein $\mathrm{A}$ was added and the incubation continued for $15 \mathrm{~min}$ at room temperature before centrifuging bound material at $12,000 \mathrm{~g}$ for $5 \mathrm{~min}$. Standard curves were analyzed by logit transformation in which logit $B$ was plotted versus log tPA concentration. Logit $B=\ln (B / 100-B)$, where $B$ is the radioactivity bound in a test sample expressed as a percentage of the radioactivity bound in the zero standard sample, corrected for nonspecific binding. Standard curves were linear between 10 and $1,000 \mathrm{pg}$, with $50 \%$ displacement at $\sim 120 \mathrm{pg}$. Nonspecific binding was $<2 \%$. This assay measures both free tPA and tPA bound to PA-I and can detect as little as $25 \mathrm{pg}$ of tPA.

Assay of PA-I activity. Inhibitory activity was measured by titration of residual uPA activity using the coupled esterolytic assay as described previously $(11,17)$. Serial dilutions of conditioned medium made with unconditioned serum-free medium containing hirudin were incubated with uPA for $10 \mathrm{~min}$ at $37^{\circ} \mathrm{C}$ before initiation of the activation reaction by addition of plasminogen. Each assay was performed in duplicate. That dilution that inhibited $50 \%$ of the activity of $0.54 \mathrm{fmol}$ ( 2 milliPloug units [mPU]) of uPA was defined as having $0.27 \mathrm{fmol}$ (1 mPU) of PAI activity. Results are expressed as $\mathrm{fmol} / \mathrm{cm}^{2}$ surface area.

\section{Results}

PA activity was not measurable in medium conditioned by either control or thrombin-treated cells, as assayed by both the ${ }^{125} \mathrm{I}$ fibrin plate assay or the coupled esterolytic assay. Presumably this reflects the fact that tPA released from human endothelial cells is bound to PA-I, which is present in excess in medium conditioned by these cells. In other experiments (not shown) endothelial cells were plated directly on dishes coated with ${ }^{125} \mathrm{I}$ fibrin and grown to confluence in plasminogen-depleted serum. The cultures were then incubated in plasminogen-containing serum in the presence or absence of thrombin. In neither case was any fibrinolytic activity detected above background release. In contrast, PA-I activity was readily measurable and was increased markedly by incubation of endothelial cells with thrombin.

Fig. 1 shows the time-course of thrombin stimulation of PAI activity in medium conditioned by human endothelial cells. During the first $3 \mathrm{~h}$ of incubation no increase over control levels

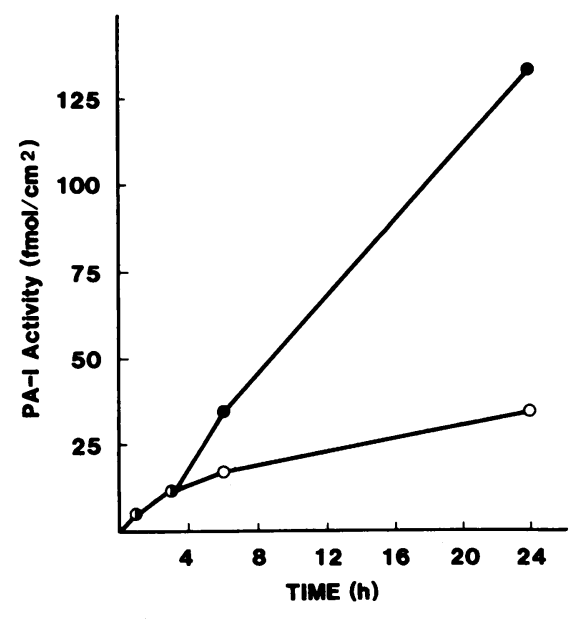

Figure 1. Time course of thrombin stimulation of PA-I activity. Confluent cultures of endothelial cells were incubated without (open circles) or with (closed circles) $2 \mathrm{U} / \mathrm{ml}$ thrombin for the times indicated. Medium was made $0.01 \%$ with Tween 80 , centrifuged to remove cell debris, and frozen. PA-I activity was measured by titration of residual uPA activity as described in Methods. Each point represents the average of duplicate assays performed on duplicate dishes.

of inhibitor activity was observed; however, at $6 \mathrm{~h}$, the medium from thrombin-treated cells contained approximately twice the levels found in control, and after $24 \mathrm{~h}$ incubation, PA-I activity was increased several-fold over that seen in the medium conditioned by control cells. After $24 \mathrm{~h}$ incubation with thrombin, PA-I activity was 5.8 \pm 1.1 -fold greater than that in control cells (mean $\pm \mathrm{SE}, n=10$ ).

The concentration dependence of the thrombin stimulation of PA-I accumulation is shown in Fig. 2, which represents the mean \pm standard error of four separate experiments. The effect of thrombin on PA-I activity was detectable at concentrations

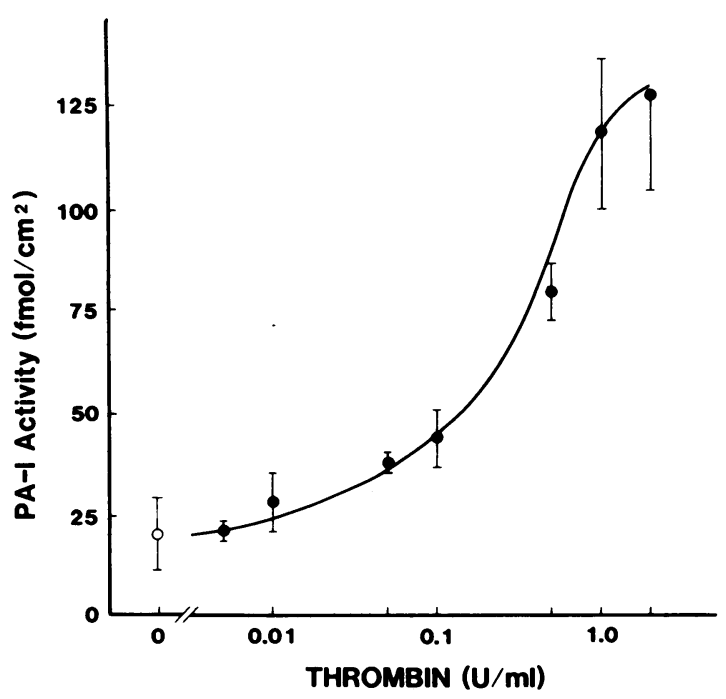

Figure 2. Concentration dependence of the thrombin stimulation of PA-I activity. Confluent cultures of endothelial cells were incubated for $24 \mathrm{~h}$ without (open circles) or with (closed circles) the indicated concentrations of thrombin. PA-I activity in the medium was measured as described in Methods. Each point represents the mean \pm SE from four separate experiments. 
Table I. Requirement for Catalytically Active $\alpha$-Thrombin for the Stimulation of PA-I

\begin{tabular}{ll}
\hline \multicolumn{1}{c}{ Treatment } & PA-I activity \\
\hline & $f m o l / \mathrm{cm}^{2}$ \\
Control & $18.8 \pm 0.9$ \\
$\alpha$-Thrombin & $53.3 \pm 4.0$ \\
$\gamma$-Thrombin & $19.0 \pm 2.3$ \\
Hirudin-thrombin & $19.8 \pm 2.1$
\end{tabular}

Endothelial cell cultures were incubated for $24 \mathrm{~h}$ without additions (control), or with $1 \mathrm{U} / \mathrm{ml} \alpha$-thrombin, or with $\gamma$-thrombin at an equivalent protein concentration $(265 \mathrm{ng} / \mathrm{ml})$, or with $1 \mathrm{U} / \mathrm{ml}$ $\alpha$-thrombin that had been catalytically inactivated by prior incubation for $20 \mathrm{~min}$ at $0^{\circ} \mathrm{C}$ with $2 \mathrm{U} / \mathrm{ml}$ hirudin. PA-I activity in the medium was assayed as described in Methods. Inhibitor activity is presented as the mean $\pm \mathrm{SE}$ from four separate experiments.

above $0.01 \mathrm{NIH} \mathrm{U/ml} \mathrm{and} \mathrm{was} \mathrm{maximal} \mathrm{at} 1-2 \mathrm{U} / \mathrm{ml}$. The effect was half-maximal at $\sim 0.4 \mathrm{U} / \mathrm{ml}(<4 \mathrm{nM})$. The concentration of active thrombin in the circulation during clotting is not known with certainty, but is estimated to be $60-90 \mathrm{nM}(6)$.

As shown in Table I, the stimulation of PA-I activity requires catalytically active $\alpha$-thrombin. $\gamma$-Thrombin, which hydrolyzes nitroanalide substrates with an efficiency close to that of $\alpha$ thrombin, but is $>2,000$-fold less effective in clotting fibrinogen $(6,22)$ and in releasing fibrinopeptide A (Shafer, J. A., personal communication), did not stimulate PA-I activity. Thrombin catalytically inactivated with hirudin also failed to enhance PAI activity, indicating the requirement for catalytically active $\alpha$ thrombin.

The stimulation of PA-I activity by thrombin requires concomitant protein and RNA synthesis, as indicated by the fact that it is blocked by cycloheximide and actinomycin D (Table II). $50 \mu \mathrm{M}$ cycloheximide, which inhibits amino acid incorporation into protein by more than $75 \%$, completely blocked the accumulation of PA-I activity in medium conditioned by both control and thrombin-treated endothelial cells. Actinomycin D at $0.16 \mu \mathrm{M}$, which inhibited DNA-dependent RNA synthesis by $90 \%$, similarly blocked the appearance of PA-I activity in the medium.

Table II. Effect of Cycloheximide and Actinomycin D on the Thrombin Induction of PA-I Activity

\begin{tabular}{lll} 
& \multicolumn{1}{c}{ PA-I activity } & \\
\cline { 2 - 3 } Inhibitor & Control & Thrombin \\
\hline & $\mathrm{fmol} / \mathrm{cm}^{2}$ & $\mathrm{fmol} / \mathrm{cm}^{2}$ \\
None & $22 \pm 7$ & $95 \pm 18$ \\
Cycloheximide & $<6$ & $<6$ \\
Actinomycin D & $6 \pm 1$ & $<6$
\end{tabular}

Endothelial cell cultures were incubated for $30 \mathrm{~min}$ with $0.1 \mathrm{mM}$ cycloheximide, $0.16 \mu \mathrm{M}$ actinomycin $\mathrm{D}$, or no inhibitor, and then for a further 18-24 h with or without $2 \mathrm{U} / \mathrm{ml}$ thrombin. PA-I activity was assayed in the medium as described in Methods, and is presented as the mean $\pm \mathrm{SE}$ from three separate experiments. The limit of detection for this assay was $6 \mathrm{fmol} / \mathrm{cm}^{2}$.

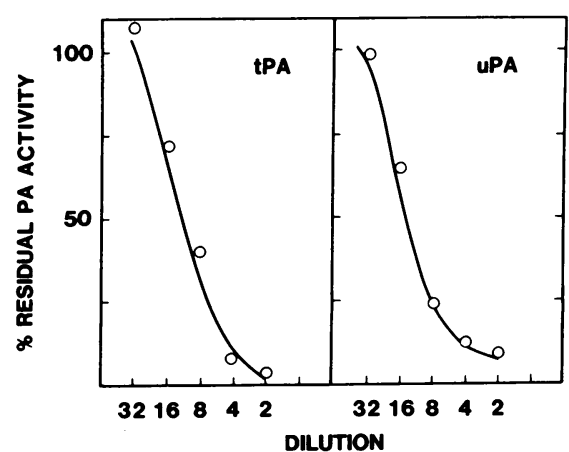

Figure 3. Inhibition of both tPA and uPA by thrombin-induced PA-I. Medium pooled from two endothelial cell cultures incubated with 1 $\mathrm{U} / \mathrm{ml}$ thrombin for $24 \mathrm{~h}$ was assayed for inhibitor activity against both tPA and UPA using the coupled esterolytic assay. Inhibition of uPA was assayed as described in Methods; $100 \%$ activity represents that of $0.54 \mathrm{fmol}$ uPA. Inhibition of tPA activity was determined using the same assay in the presence of $220 \mu \mathrm{g} / \mathrm{ml}$ cyanogen bromide-digested fibrinogen; $100 \%$ activity represents that of $0.5 \mathrm{fmol}$ tPA. Each point represents the average of duplicate assays.

The properties of the thrombin-induced endothelial cell PAI are the same as those previously described by us for the PA-I induced by glucocorticoids in rat hepatoma cells (10-13) and by others for the PA-I in human plasma (23-26), platelets (7), and cultured human (2-4) and bovine endothelial cells $(5,27)$. As shown in Fig. 3, the thrombin-induced inhibitor rapidly inhibits both tPA and UPA with similar potency. PA-I activity in this sample was $63 \mathrm{fmol} / \mathrm{cm}^{2}$ when assayed against tPA, and 73 $\mathrm{fmol} / \mathrm{cm}^{2}$ against uPA. Second, as shown in Table III, the inhibitor did not lose activity upon incubation at $\mathrm{pH} 3$ for $1 \mathrm{~h}$ at room temperature, a treatment which destroys the activity of most plasma protease inhibitors, including $\alpha_{2}$ anti-plasmin (28), as well as the activity of the placenta PA-I (29) and of a fibroblast PA-I called protease nexin (30), but not that of either the endothelial (2-5) or hepatoma (10-12) PA-I. Finally, as shown in Fig. 4, the inhibitory activity was also stable to sodium dodecyl sulfate (SDS) and thiol reduction. Incubation of medium from thrombin-treated cultures with $0.1 \%$ SDS and $0.1 \%$ 2-mercaptoethanol for $1 \mathrm{~h}$ at $37^{\circ} \mathrm{C}$, followed by extensive dialysis, in fact, increased inhibitory activity approximately eightfold (from 112

Table III. Acid Stability of the PA-I

\begin{tabular}{llc} 
& PA-I activity & \\
\cline { 2 - 3 } & Control & Acidified \\
\hline & $\mathrm{fmol} / \mathrm{cm}^{2}$ & $\mathrm{fmol} / \mathrm{cm}^{2}$ \\
Control & 25 & 20 \\
$\alpha$-Thrombin & 123 & 112
\end{tabular}

To $1 \mathrm{ml}$ of medium from control or thrombin-treated endothelial cells, $30 \mu$ of $1 \mathrm{~N} \mathrm{HCl}$ was added to reduce the $\mathrm{pH}$ to 3.2. After $1 \mathrm{~h}$ incubation at room temperature, $25 \mu \mathrm{l}$ of $1 \mathrm{~N} \mathrm{NaOH}$ was added to restore the $\mathrm{pH}$ to 7.4 . As a control, $1 \mathrm{ml}$ of medium from thrombintreated and untreated cells was incubated for $1 \mathrm{~h}$ with a mixture of $\mathrm{HCl}$ and $\mathrm{NaOH}$. PA-I activity was assayed by titration of uPA esterolytic activity as described in Methods. Each datum represents the mean of duplicate assays on duplicate samples. 


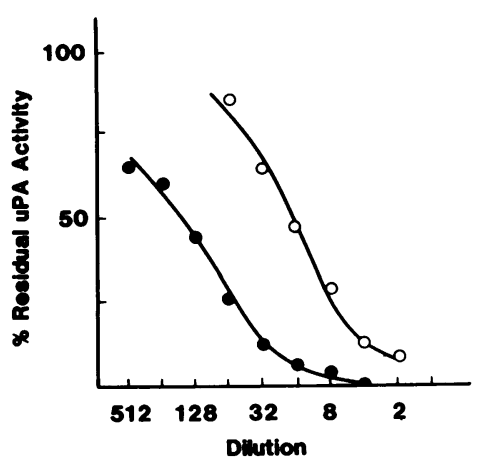
saline, $\mathrm{pH} 7.4$, containing $0.01 \%$ Tween 80 and $0.02 \%$ sodium azide. PA-I activity was assayed by titration of residual uPA activity as described in Methods.

to $896 \mathrm{fmol} / \mathrm{cm}^{2}$ in this sample). A similar activation of PA-I has been observed in both rat hepatoma cells and bovine endothelial cells (31).

Although no PA activity could be measured in the medium conditioned by either control or thrombin-treated cells, Levin and co-workers (32) have previously reported that thrombin increases the concentration of IPA antigen in medium conditioned by thrombin-treated cells. Primary cultures of human endothelial cells produce only tPA but not uPA (2-4). We measured tPA antigen by a radioimmunoassay that detects and quantitates both free tPA as well as tPA bound to PA-I. To demonstrate this, 2 ng tPA was mixed with a $500 \mu \mathrm{l}$ sample of endothelial cellconditioned medium containing sufficient PA-I activity $(\sim 200$ fmol) to completely neutralize the added tPA, and the mixture was incubated for $1 \mathrm{~h}$ at $37^{\circ} \mathrm{C}$ to allow complex formation. No tPA activity was measurable in the endothelial cell medium before or after addition of the exogenous tPA. Radioimmunoassay of tPA antigen revealed $0.27 \mathrm{ng}$ tPA in the medium before, and $2.15 \pm 0.23 \mathrm{ng}$ (mean $\pm \mathrm{SE}$ of four dilutions assayed in duplicate) after adding $2 \mathrm{ng}$ tPA to the medium. Using this assay, we have confirmed that thrombin increases tPA concentration in medium conditioned by human endothelial cells by approximately fourfold (from $2.6 \pm 0.6$ to $9.2 \pm 1.8 \mathrm{fmol} / \mathrm{cm}^{2}$; mean $\pm \mathrm{SE}, n=6$ ). The time course and concentration dependence of the thrombin enhancement of tPA antigen levels in the medium (data not shown) is similar to that for PA-I activity. It should be noted, however, that the concentration of tPA in the medium from both control and thrombin-treated cells is approximately 10-fold lower than the concentration of active PA-I.

\section{Discussion}

We report here that physiological concentrations of thrombin increase PA-I activity, and tPA antigen, in serum-free medium conditioned by human umbilical vein endothelial cells. Because there was always a several-fold increase in the net activity of free PA-I, the net effect of thrombin may be to decrease fibrinolytic activity in medium conditioned by human endothelial cells. Thus, thrombin, in addition to its role in coagulation, may protect clots from premature lysis by increasing the amount of a specific fibrinolytic inhibitor.

These observations provide further evidence that human vascular endothelium may play a significant role in fibrinolysis as well as in hemostasis, and that thrombin can modulate the fibrinolytic system in addition to its multiple effects on hemostatic processes. Thrombin is known to cause release of PA-I from human platelets (7) and to inhibit PA activity in medium conditioned by bovine aortic endothelial cells (8). Our observations that thrombin can decrease fibrinolytic activity in human endothelial cells by inducing PA-I are consistent with the conclusion that thrombin both enhances hemostasis and inhibits fibrinolysis.

The effects of thrombin on fibrinolysis, however, may be more complex. Thrombin, in the presence of thrombomodulin, activates protein-C, which enhances fibrinolytic activity in several experimental systems (9). Incubation of cultured human endothelial cells with active protein- $C$ decreases the accumulation of PA-I in the medium, which secondarily increases PA activity; there is no effect on the accumulation of tPA antigen. The effect of active protein- $C$ can be demonstrated in cell-free medium and may result from the direct proteolytic cleavage of PA-I (33). The thrombin stimulation of tPA antigen release by human endothelial cells reported by Levin et al. (32), and by us, also suggests that thrombin might have fibrinolytic effects as well.

It is becoming apparent that fibrinolysis is regulated, at least in part, by a balance between PA and PA-I. The 10-fold excess of inhibitor relative to PA observed in cultured human umbilical vein endothelial cells by us and others (2-4) is not an exact representation of the in vivo situation; however, there is substantial evidence that in vivo, most if not all of the circulating tPA is bound to PA-I (34). Estimates of blood tPA activity (23, $24,34-36)$ range from 0.2 to $2 \mathrm{ng} / \mathrm{ml}(3-30 \mathrm{pM})$; whereas tPA antigen $(21,34)$ is $\sim 5-10 \mathrm{ng} / \mathrm{ml}(75-150 \mathrm{pM})$. Measurement of PA-I activity has varied widely in different individuals and has ranged from 0 to $120 \mathrm{ng} / \mathrm{ml}(0-2.4 \mathrm{nM})$ with an average of $\sim 1 \mathrm{nM}(23-26,34,35)$. Thus, tPA in the circulation also exists predominantly as a $100,000-\mathrm{D}$ complex with inhibitor.

Other factors, in addition to thrombin, can regulate PA-I activity in blood. Endotoxin enhances PA-I release by endothelial cells in vivo and in vitro (37), and the anabolic steroid stanozolol has been shown to increase fibrinolytic activity in vivo by decreasing PA-I activity rather than by increasing the amount of tPA (38). Finally, there is increasing evidence that PA-I plays an important role in thromboembolic disease $(26,39)$, and a family has been reported with an autosomal dominant thromboembolic disorder presumably secondary to increased levels of circulating PA-I (40).

\section{Acknowledgments}

The authors thank Dr. S. Weiss and Ms. S. Regiani for providing cultures of human umbilical vein endothelial cells; Dr. J. W. Fenton II for gifts of $\alpha$ - and $\gamma$-thrombin; Genentech, Inc. for recombinant human tPA; Dr. Desire Collen for anti-tPA antiserum; and Dr. Jules Shafer for constructive criticism. We also thank Ms. Anna Huttenlocher for technical help in the beginning of this project and Ms. J. Worley for typing the manuscript.

This work was supported by National Institutes of Health grant CA 22729 .

\section{References}

1. Erickson, L. A., R. R. Schleef, T. Ny, and D. J. Loskutoff. 1985. The fibrinolytic system of the vascular wall. Clin. Haematol. 14:513530.

2. Philips, M., A.-G. Juul, and S. Thorsen. 1984. Human endothelial 
cells produce a plasminogen activator-inhibitor complex. Biochim. Biophys. Acta. 802:99-110.

3. Sprengers, E. D., J. H. Verheijen, V. W. M. Van Hinsberg, and J. J. Emeis. 1984. Evidence for the presence of two different fibrinolytic inhibitors in human endothelial cell conditioned medium. Biochim. Biophys. Acta. 801:163-171.

4. Levin, E. G. 1983. Latent tissue plasminogen activator produced by human endothelial cells in culture. Evidence for an enzyme inhibitor complex. Proc. Natl. Acad. Sci. USA. 80:6804-6808.

5. Loskutoff, D. J., J. A. van Mourik, L. A. Erickson, and D. Lawrence. 1983. Detection of an unusually stable fibrinolytic inhibitor produced by bovine endothelial cells. Proc. Natl. Acad. Sci. USA. 80:2956-2960.

6. Fenton, J. W., II. 1981. Thrombin specificity. Ann. NY Acad. Sci. 370:468-495.

7. Erickson, L. A., M. H. Ginsberg, and D. J. Loskutoff. 1984. Detection and partial characterization of an inhibitor of plasminogen activator in human platelets. J. Clin. Invest. 74:1465-1472.

8. Loskutoff, D. J. 1979. Effect of thrombin on the fibrinolytic activity of cultured bovine endothelial cells. J. Clin. Invest. 64:329-332.

9. Esmon, C. T. 1983. Protein-C: biochemistry, physiology, and clinical implications. Blood. 62:1155-1158.

10. Seifert, S. C., and T. D. Gelehrter. 1978. Mechanism of glucocorticoid inhibition of plasminogen activator in rat hepatoma cells. Proc. Natl. Acad. Sci. USA. 75:6130-6133.

11. Coleman, P. L., P. A. Barouski-Miller, and T. D. Gelehrter. 1982. The dexamethasone-induced inhibitor of fibrinolytic activity in hepatoma cells: a cellular product which specifically inhibits plasminogen activation. J. Biol. Chem. 257:4260-4264.

12. Gelehrter, T. D., P. A. Barouski-Miller, P. L. Coleman, and B. J. Cwikel. 1983. Hormonal regulation of plasminogen activator in rat hepatoma cells. Mol. Cell. Biochem. 53/54:11-21.

13. Cwikel, B. J., P. A. Barouski-Miller, P. L. Coleman, and T. D. Gelehrter. 1984. Dexamethasone induction of an inhibitor of plasminogen activator in HTC rat hepatoma cells. J. Biol. Chem. 259:68476851 .

14. Deutsch, D. G., and E. T. Mertz. 1970. Plasminogen: purification from human plasma by affinity chromatography. Science (Wash. DC). 170:1095-1096.

15. Jaffe, E. A., R. L. Nachman, C. G. Becker, and C. R. Minick. 1973. Culture of human endothelial cells derived from unbilical veins. J. Clin. Invest. 52:2745-2756.

16. Maciag, T., G. A. Hoover, M. B. Stemerman, and R. Weinstein. 1981. Serial propagation of human endothelial cells in vitro. J. Cell Biol. 91:420-426.

17. Coleman, P. L., and G. D. J. Green. 1981. A sensitive, coupled assay for plasminogen activator using a thiol ester substrate for plasmin. Ann. NY Acad. Sci. 370:617-626.

18. Verheijen, J. H., E. Mullaart, G. T. G. Chang, C. Kluft, and G. Wijngaards. 1982. A simple, sensitive spectrophotometric assay for extrinsic (tissue-type) plasminogen activator applicable to measurements in plasma. Thromb. Haemostasis. 48:266-269.

19. Fraker, P. J., and J. C. Speck. 1978. Protein and cell membrane iodinations with a sparingly soluble chloroamide $1,3,4,6$-tetrachloro3a, 6a-diphenylglyouril. Biochem. Biophys. Res. Commun. 80:849-857.

20. Heaton, J. H., N. L. Krett, J. M. Alvarez, T. D. Gelehrter, J. A. Romanus, and M. M. Rechler. 1984. Insulin regulation of insulin-like growth factor action in rat hepatoma cells. J. Biol. Chem. 259:23962402.

21. MacGregor, I. R., and C. V. Prowse. 1983. Tissue plasminogen activator in human plasma measured by radioimmunoassay. Thromb. Res. 31:461-474.
22. Biossel, J.-P., B. LeBonniec, M.-J. Rabiet, D. Labie, and J. Elion. 1984. Covalent structures of $\beta$ and $\gamma$ autolytic derivatives of human $\alpha$ thrombin. J. Biol. Chem. 259:5691-5697.

23. Kruithof, E. K. O., C. Tran-Thang, A. Ransijn, and F. Bachmann. 1984. Demonstration of a fast-acting inhibitor of plasminogen activators in human plasma. Blood. 64:907-913.

24. Verheijen, J. H., G. T. G. Chang, and C. Kluft. 1984. Evidence for the occurrence of a fast-acting inhibitor for tissue-type plasminogen activator in human plasma. Thromb. Haemostasis. 51:392-395.

25. Wiman, B., J. Chmielewska, and M. Ranby. 1984. Inactivation of tissue plasminogen activator in plasma. J. Biol. Chem. 259:36443647.

26. Juhan-Vague, I., B. Moerman, F. DeCock, M. F. Aillaud, and D. Collen. 1984. Plasma levels of a specific inhibitor of tissue-type plasminogen activator (and urokinase) in normal and pathological conditions. Thromb. Res. 33:523-530.

27. van Mourik, J. A., D. A. Lawrence, and D. J. Loskutoff. 1984. Purification of an inhibitor of plasminogen activator (antiactivator) synthesized by endothelial cells. J. Biol. Chem. 259:14914-14921.

28. Travis, J., and G. S. Salvesen. 1983. Human plasma proteinase inhibitors. Annu. Rev. Biochem. 52:655-709.

29. Kawano, T., K. Morimoto, and Y. Uemura. 1979. Partial purification and properties of urokinase inhibitor from human placenta. J. Biochem. (Tokyo). 67:333-342.

30. Eaton, D. L., R. W. Scott, and J. B. Baker. 1984. Purification of human fibroblast urokinase proenzyme and analysis of its regulation by proteases and protease nexin. J. Biol. Chem. 259:6241-6247.

31. Loskutoff, D. J., K. Roegner, L. A. Erickson, R. R. Schleef, A. Huttenlocher, P. L. Coleman, and T. D. Gelehrter. 1986. The dexamethasone-induced inhibitor of plasminogen activator in hepatoma cells is antigenically related to an inhibitor produced by bovine aortic endothelial cells. Thromb. Haemostasis. In press.

32. Levin, E. G., U. Marzec, J. Anderson, and L. A. Harker. 1984. Thrombin stimulates tissue plasminogen activator release from cultured human endothelial cells. J. Clin. invest. 74:1988-1995.

33. van Hinsbergh, V. W. M., R. M. Bertina, A. van Wijngaarden, N. H. van Tilburg, J. J. Emeis, and F. Haverkate. 1985. Activated protein C decreases plasminogen activator inhibitor activity in endothelial cellconditioned medium. Blood. 65:444-451.

34. Bachmann, F., and E. K. O. Kruithof. 1984. Tissue plasminogen activator: chemical and physiological aspects. Semin. Thromb. Hemostasis. 10:6-17.

35. Chmielewska, J., M. Ranby, and B. Wiman. 1983. Evidence for a rapid inhibitor to tissue plasminogen activator in plasma. Thromb. Res. 31:427-436.

36. Wun, T.-C., and A. Capuano. 1985. Spontaneous fibrinolysis in whole human plasma. J. Biol. Chem. 260:5061-5066.

37. Colucci, M., J. A. Paramo, and D. Collen. 1985. Generation in plasma of a fast-acting inhibitor of plasminogen activator in response to endotoxin stimulation. J. Clin. Invest. 75:818-824.

38. Verheijen, J. H., D. C. Rijken, G. T. G. Chang, F. E. Preston, and C. Kluft. 1984. Modulation of rapid plasminogen activator inhibitor in plasma by stanozolol. Thromb. Haemostasis. 51:396-397.

39. Wiman, B., B. Ljungberg, J. Chmielewska, G. Urdén, M. Blomback, and H. Johnsson. 1985. The role of the fibrinolytic system in deep vein thrombosis. J. Lab. Clin. Med. 105:265-270.

40. Nilsson, I. M., and L. Tengborn. 1984. A family with thrombosis associated with high level of tissue plasminogen activator inhibitor. Haemostasis. 14:24. (Abstr.) 